\title{
PKM USAHA RUMAH MAKAN DI KELURAHAN TINGKULU KECAMATAN TIKALA KOTA MANADO
}

\section{Imelda W J Ogi, Joy Elly Tulung, Michael Ch Raintung}

Universitas Sam Ratulangi

A R T I C LE INF O

Keywords : Entrepreneurship,
UMKM

Kata Kunci : Kewirausahaan, $U M K M$

Corresponding author :

Imelda W.J Ogi

ogi.imelda@unsrat.ac.id

\begin{abstract}
Tikala Subdistrict is one area that was in Manado that the growth rate of business diner look very significant, which can be seen in sepangjang Subdistrict Tikala roads filled with this venture. Especially in the area of business diner is prima donna for the people of the city of Manado and the area around Manado city even for travelers from outside the region makes the ultimate choice to find culinary tour, this makes the trade house eating bersekala micro small and medium enterprises to create their business better so that it can compete with the efforts of a large scale. The activities of PKM business group Restaurants at Kel. Tingkulu Kec. Tikala Manado City. These activities have business partners as the target of this activity, namely entrepreneurs micro small and medium enterprises which are in the sights of the culinary in Kelurahan Tingkulu Kec. Tikala Manado city. The implementation of the activities of the PKM Venture restaurants in Warong Kobong Manado city.
\end{abstract}

Abstrak : Kecamatan Tikala merupakan salah satu daerah yang berada di kota Manado yang tingkat pertumbuhan usaha rumah makan terlihat sangat signifikan dimana dapat dilihat di sepangjang ruas jalan Kecamatan Tikala dipenuhi dengan usaha ini. Khususnya di daerah usaha rumah makan merupakan primadona bagi masyarakat kota Manado dan daerah sekitar kota Manado bahkan bagi pelancong yang berasal dari luar daerah menjadikan pilihan utama untuk mencari wisata kuliner, hal ini membuat para pelaku usaha rumah makan yang bersekala mikro kecil dan menengah untuk bisa memanajemen usaha mereka dengan lebih baik sehingga dapat bersaing dengan usaha-usaha rumah makan yang berskala besar.Kegiatan PKM Kelompok Usaha Rumah Makan dilaksanakan di Kel. Tingkulu Kec. Tikala Kota Manado. Kegiatan ini memiliki mitra usaha sebagai sasaran dari kegiatan ini yaitu para pengusaha mikro kecil dan menengah yang berada di objek wisata kuliner di Kelurahan Tingkulu Kec. Tikala kota Manado. Pelaksanaan kegiatan PKM Usaha Rumah Makan di Warong Kobong Kota Manado. 


\section{PENDAHULUAN}

\section{Analisis Situasi}

Usaha kecil menengah umumnya dapat bertahan terhadap krisis ekonomi, namun kemampuan untuk berkembang sangat penting menghadapi persaingan usaha yang ketat di era globalisasi. Sebagian besar para pengusaha kecil ataupun menengah memiliki keterbatasan baik dalam kemampuan modal, SDM, akses informasi, maupun teknologi. Sebagian besar pedagang sulit untuk berkembang dikarenakan kurangnya pengetahuan dalam mengembangkan usahanya. Berdasarkan survey awal yang dilakukan terhadap pada usaha rumah makan di Kelurahan Tingkulu Kecamatan Tikala merupakan salah satu lokasi yang paling ramai di Kota Manado, dimana usaha rumah makan merupakan salah satu pendapatan bagi masyarakat sekitar. Penginvestasian dana merupakan tolok ukur besar kecilnya suatu perusahaan, baik dilihat dari segi aspek laba, risiko usaha maupun likuiditasnya. Pengaturan kombinasi sumber dana (hutang dan modal sendiri) berikut kebijakan deviden merupakan penentu besar kecilnya beban financial dan risiko finansial. Semua variabel tersebut akan mempengaruhi penilaian perusahaan secara keseluruhan. Setiap perusahaan selalu membutuhkan dana dalam rangka memenuhi kebutuhan operasi sehari - hari maupun untuk mengembangkan perusahaan. Kebutuhan dana tersebut berupa modal kerja maupun untuk pembelian aktiva tetap. Untuk memenuhi kebutuhan dana tersebut para wirausaha harus mampu mencari sumber dana dengan komposisi yang menghasilkan beban biaya yang murah.

Kemajuan perekonomian yang semakin kompetitif memunculkan banyak pengusaha atau pebisnis semakin kreatif, inovatif bahkan modern dengan pengetahuan dan peralatan yang mereka miliki. Kebanyakan para pengusaha seperti ini juga sudah memiliki modal usaha, skill seperti ilmu pengetahuan dalam mengelola modal usaha dan pengalaman dalam menjalankan usahanya dengan baik dalam mengembangkan usaha mereka. Sayangnya di pihak lain, hal tersebut menimbulkan dampak yang merugikan bagi para pedagang kecil dimana kebanyakan mereka hanya memiliki pengetahuan yang terbatas, demikian juga dengan modal untuk mengembangkan usaha mereka. Berdasarkan fenomena tersebut, maka tim pengabdian tertarik untuk melakukan kegiatan pengabdian bagi para usaha rumah makan yang berlokasi di Kelurahan Tingkulu. Adapun yang dijadikan mitra dalam pengabdian ini yakni para pemilik usaha rumah makan berlokasi di Kelurahan Tingkulu Kecamatan Tikala. Penduduk yang menetap di kelurahan Tingkulu ini karakteristik pekerjaan penduduknya cukup beragam yaitu wiraswasta, buruh, dan pegawai.

Letak kelurahan Tingkulu ini cukup strategis untuk pengembangan usaha karena berada di pusat Kota Manado yang sehari-harinya dipadati oleh kendaraan yang melintas. Peluang ini sebenarnya sudah dilihat oleh sebagian kecil penduduk yang bergelut di bidang usaha kecil menengah dimana mereka mendirikan kios-kios usaha mereka di Kelurahan Tingkulu Kecamatan Tikala.

Usaha rumah makan tentu sangat menguntungkan jika dikelola dengan baik karena pihak-pihak yang merasakan manfaatnya bukan hanya para pengusaha tetapi juga masyarakat di sekitarnya. Seperti yang sudah dikemukakan sebelumnya, peluang usaha yang menjanjikan tentunya perlu ditunjang dengan kemampuan ketrampilan pengelolaan modal yang baik dan semangat wirausah. Secara teori keberhasilan seorang pedagang ditentukan oleh kemampuannya menjual ide serta mengelola ide tersebut. Hal ini melibatkan pengetahuan, pengalaman, inisiatif dan kecerdasan. Kemampuan pedagang juga meliputi kemampuan untuk mengelola keuangan dengan cermat dalam hal ini modal kerja dan pendapatan serta kemampuan memasarkan produknya. Selama ini pemasaran hanya dilakukan di kios-kios yang tentunya hal ini membatasi para pembeli yang berada di kelurahan Tingkulu . Kondisi ini berdampak langsung terhadap tingkat pendapatan mereka. Tingkat pendapatan yang baik tentunya menjamin kesinambungan usaha yang baik, demikian juga sebaliknya. 


\section{Permasalahan Mitra}

Berdasarkan gap (kesenjangan) pada pendahuluan maka dirumuskan masalah sebagai berikut : Bagaimanakah cara agar usaha rumah makan yang berada di Kelurahan Tingkulu dapat memperoleh dan menguasai teknik dan pengetahuan untuk melakukan pengembangan usaha dan pengelolaan modal kerja yang efektif dan efisien sehingga menjamin kesinambungan usahanya.

Untuk memperjelas rumusan masalah maka diberikan batasan terhadap ruang lingkup masalah sesuai dengan hasil Survey Awal yang dilakukan, sebagai berikut:

1. Pengusaha kecil adalah pengusaha yang memiliki kekayaan bersih paling banyak 50 juta-500 juta ( tidak termasuk tanah dan bangunan tempat usaha atau memiliki hasil penjualan tahunan paling banyak 300 juta -2.5 milyar

2. Kelompok usaha rumah makan adalah masyarakat yang menjual makanan dan minuman .

3. Modal kerja adalah modal atau uang yang harus dimiliki oleh pengusaha untuk membiayai operasional usahanya sehari-hari.

\section{Tujuan Penerapan PKM}

1. Memberikan pelatihan teknik kepada kelompok penjual usaha rumah makan

2. Memberikan pengetahuan manajerial tentang pengembangan usaha dan meningkatkan kinerja usaha

\section{TARGET DAN LUARAN}

Target luaran yang diharapkan adalah kelompok pengusaha rumah makan yaitu peserta memiliki peningkatan pemahaman dan pengetahuan mengenai manajemen pengembangan usaha dan pengelolaan modal kerja yang berguna untuk pengelolaan keuangan baik secara individu maupun berkelompok dalam lingkungan maupun dalam bersosialisasi di tengah masyarakat.

Manfaat dari kegiatan ini yang diharapkan terwujud adalah :

a. $\quad$ Sisi ekonomi : Peserta dapat meningkatkan dan mengembangkan diri yang akan berdampak pada kemauan untuk meningkatkan modal usaha mereka dan pengembangan usaha pada akhirnya

b. Memberikan peningkatan pendapatan dan kesejahteraan.

c. Sisi penerapan Ipteks: Peserta dapat menjadi "trainer" bagi para kelompok pedagang lainnya.

\section{Kelayakan PT}

Adapun kelayakan yang dimiliki tim pengabdian yakni :

a. Kualifikasi Tim Pelaksana adalah tim yang berasal dari Fakultas Ekonomi Dan Bisnis Unsrat yang terdiri dari satu orang ketua dan dibantu satu orang anggota, tentunya tim ini memiliki pengetahuan yang baik tentang wirausaha dan sudah berpengalaman dalam kemasyarakatan karena sudah beberapa kali melakukan kegiatan pengabdian masyarakat walaupun dalam kelompok yang berbeda-beda.

b. Relevansi Skill Tim

Seperti telah diungkapkan sebelumnya, tim memiliki pengalaman dalam organisasi sosial politik, kemasyarakatan dan gereja sehingga dalam pelaksanaan kegiatan pengabdian kepada masyarakat tidak diragukan. Tim juga merupakan dosen yang telah memiliki pengalaman mengajar yang memadai khususnya ketua tim pengabdian. Bidang keahlian akademik yang dimiliki oleh tim sesuai dengan topik atau materi pelatihan yang akan dilaksanakan sehingga diharapkan kegiatan yang dimaksud akan memberikan kontribusi yang maksimal baik bagi tim dan juga bagi masyarakat peserta pelatihan.

c. $\quad$ Sinergisme Tim

Dalam pelaksanaan kegiatan pengabdian kepada masyarakat ini sesama anggota tim saling berkoordinasi dan selalu mengupayakan adanya komunikasi yang baik antara sesama anggota tim mulai dari survey awal di 
lapangan sampai pelaksanaan pelatihan, sehingga hal ini bisa menunjang pelaksanaan kegiatan yang dimaksud.

\section{METODE PELAKSANAAN}

Adapun metode yang ditempuh tim pengabdian yaitu metode pelatihan kepada para pemilik rumah makan dalam bentuk ceramah dan tanya jawab. Pelatihan yang dimaksud menyangkut teknik dan pengetahuan pengembangan usaha dengan membuat business plan atau perencanaan bisnis dan cara pengelolaan modal kerja agar terjadi kesinambungan usaha yang lebih efektif dan efisien. Materi dalam pelatihan antara lain meliputi pembuatan perencanaan bisnis dan pengelolaan modal kerja, dengan metode studi kasus untuk membantu melatih mereka dalam menyusun atau membuat laporan keuangan dan proposal perencanaan bisnis/business plan. Setelah itu peserta diberikan pemahaman tentang motivasi agar memiliki semangat wirausaha yang tinggi.

Berikut adalah tabel berupa metode yang disampaikan kepada peserta.

Tabel 1. Metode Pelatihan

\begin{tabular}{|c|c|c|c|}
\hline No. & Materi & Alokasi Waktu & Metode Pelatihan \\
\hline 1 & Pembuatan Business Plan & 3 jam & $\begin{array}{l}\text { 1.Ceramah } \\
\text { 2. Praktek } \\
\text { 3. Diskusi/Tanya Jawab }\end{array}$ \\
\hline 2 & Pelatihan & 3 jam & $\begin{array}{l}\text { 1.Ceramah } \\
\text { 2. Praktek } \\
\text { 3. Diskusi/Tanya Jawab }\end{array}$ \\
\hline 3 & Enterpreneurship & 2 jam & $\begin{array}{l}\text { 1.Ceramah } \\
\text { 2.Diskusi/Tanya Jawab }\end{array}$ \\
\hline
\end{tabular}

Adapun gambaran umum metode pelaksanaan kegiatan yang dilakukan dapat dilihat pada gambar berikut ini.

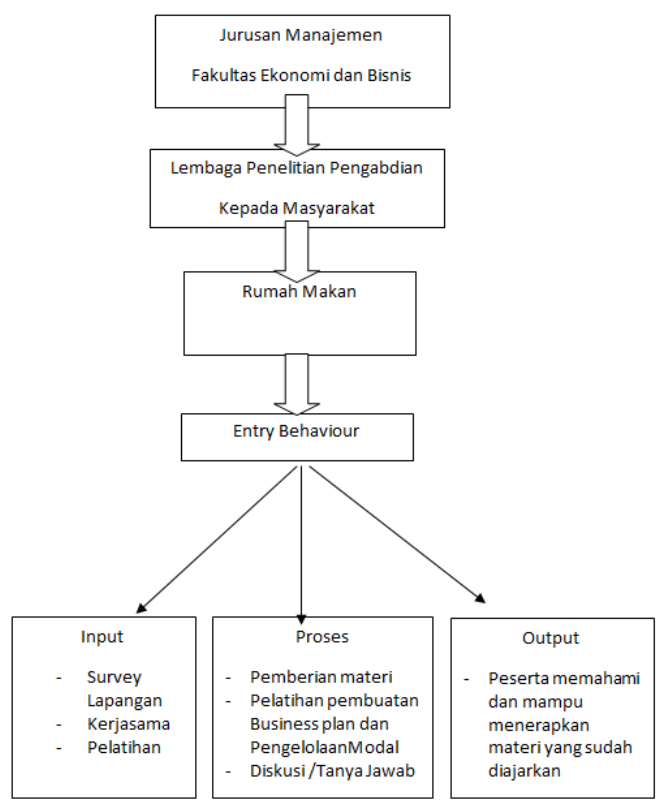

Gambar 1. Gambaran penerapan PKM 


\section{HASIL DAN LUARAN YANG DICAPAI}

\section{Profil Mitra PKM}

Pelaksanaan Program Kemitraan Masyarakat yang dilaksanakan oleh Tim Pengusul FEB Unsrat pada Usaha Rumah makan di Di Kelurahan Tingkulu Kecamatan Tikala Kota Manado . Kelompok usaha mitra adalah kelompok usaha kecil menengah yang mewadahi kelompok usaha-kelompok usaha kecil yang ada di Di Kelurahan Tingkulu Kecamatan Tikala Kota Manado Provinsi Sulawesi Utara. Usaha Kecil ini yang bergerak di bidang kuliner didirikan dengan modal yang berasal dari pemiliknya sendiri dengan memanfaatkan lahan tempat tinggalnya yang merupakan hak milik dari pengusaha tersebut sebagai asset usahanya. Dengan demikian, para pelaku usaha ini sangat membutuhkan strategi-strategi dalam mengembangkan usaha mereka kedepan dikarenakan terdapat banyak pesaing (competitor) di sekitar tempat mereka membuka usaha. Hal ini tentunya harus dibarengi dengan kemampuan yang mereka miliki saat ini dalam mengembangkan dan mempertahankan usaha mereka.

\section{Analisa Kebutuhan}

Dalam perkembangan usaha ini para pemilik menyadari akan pentingnya pelatihan dan pengembangan Menjadi wirausaha sukses dalam persaingan usaha saat ini, dimana dalam hal ini salah satu komitmen untuk mendukung kegiatan dan program pemerintah dengan tujuan pertumbuhan ekonomi nasional sehingga seluruh masyarakat bisa sejahtera. Sebelum kegiatan pelatihan dan pengembangan dilakukan, Tim telah turun lapangan (survey) untuk pengambilan data awal, dimana hal ini dilakukan untuk mengetahui apa yang menjadi masalah dan kebutuhan masyarakat yang akan menjadi mitra kerja dalam kegiatan Program Kemitraan Masyarakat (PKM). Setelah pelatihan serta pengembangan maka akan dilakukan evaluasi dan feedback. Dimana terdapat beberapa masalah pokok, yakni: mereka kurang terlatih dalam menggunakan teknologi informasi (online business), promosi usaha yang dilakukan lebih mengandalkan word of mouth dan variasi produk yang ditawarkan cenderung mainstream (memiliki kesamaan dengan pesaing).

\section{Luaran Yang Dicapai}

Melalui kegiatan pengabdian ini para pelaku usaha mikro dan kecil menengah khususnya usaha rumah makan yang berada di Kelurahan Tingkulu Kecamatan Tikala Kota Manado Provinsi Sulawesi Utara dibekali dengan materi kewirausahaan melalui entrepreneurship class, sehingga mereka dapat mengembangkan usaha mereka untuk dapat bersaing. Dalam pengabdian ini para pelaku bisnis juga 
dibekali dengan pelatihan kewirausahaan sehingga dapat membantu para pelaku usaha dalam manajemen usaha mereka sehingga mempunyai daya saing dan dapat bersaing dengan para pelaku usaha besar.

\section{PENUTUP}

\section{Kesimpulan}

Kegiatan ini mampu memberikan pelatihan dan pengembangan untuk Menjadi wirausaha kuliner yang sukses pada di Kelurahan Tingkulu Kecamatan Tikala Kota Manado Provinsi Sulawesi Utara, meningkatkan soft skill serta hard skill bagi pemilik usaha dalam berwirausaha, sehingga menjadikan mereka lebih kreatif dan inovatif, terciptanya pelatihan manajemen usaha secara intensif, pelatihan penggunaan akses teknologi informasi baik komputer maupun internet yang berbasis bisnis online, adanya pendampingan yang dilakukan oleh pemerintah secara profesional dan berkelanjutan

\section{Saran}

Pengadaan program pelatihan, pengembangan dan evaluasi serta monitoring dari pihak pelaksana/Tim Program Kemitraan masyarakat harus dilakukan secara terus menerus (kontinuen), adanya pelatihan lebih lanjut khususnya dalam peningkatan penguatan pada pengetahuan, ketrampilan dalam berwirausaha Pada kedua mitra Rumah makan (Kuliner), peran serta dari akademisi, pelaku usaha dan pemerintah ingatlah dibutuhkan dalam hal bekerja sama baik dalam hal pelatihan dan pengembangan serta regulasi untuk menunjang usaha yang dijalankan.

\section{DAFTAR PUSTAKA}

Kotler Philip, Kevin Lane Keller, Manajemen Pemasaran, Alih Bahasa Benyamin Molan, Jilid Satu, Cetakan Kedua, Jakarta : Indeks, 2007

Robbins. Stephen. P. (2010). Manajemen. Edisi kedelapan. Jilid 2. Jakarta: PT. Indeks.

Faisal. 2002. Kalau Begitu, Saya Berani Berwirausaha. Jakarta: Bina Rena Pariwara. 